\title{
Effect of Harvest Maturity and Pre-cooling on Post Harvest Rots of Apple
}

\author{
Neelam Kumari ${ }^{{ }^{*}}$, J. N. Sharma ${ }^{2}$ and Deepika Singh ${ }^{3}$ \\ ${ }^{1}$ Krishi Vigyan Kendra Shimla, Rohru, H.P. (171 207), India \\ ${ }^{2}$ Dept. of Plant Pathology, ${ }^{3}$ Dept. of Fruit Science, Dr. Y. S. Parmar University of Horticulture and Forestry, Nauni, Solan, \\ H.P. (173 230), India
}

\section{Corresponding Author}

Neelam Kumari

e-mail: neelkumari90@gmail.com

\author{
Article History \\ Article ID: IJEP0317 \\ Received in $25^{\text {th }}$ July, 2019 \\ Received in revised form $06^{\text {th }}$ August, 2019 \\ Accepted in final form $16^{\text {th }}$ August, 2019
}

\begin{abstract}
The effects of harvest maturity and different post harvest pre-cooling methods on post harvest rotting of apple fruits were studied. The apple fruits picked later (126 DFFB) were more sensitive to rot with mean rot of 76.21\%. Early harvesting (106 DFFB) significantly resulted in minimum rotting of fruits (12.81\%). Pre-cooling treatment with HIWC (ice water and calcium chloride) for 30 min was found most effective among all other cooling medium. Minimum fruit rot (4.69\%) was recorded in the fruits pre-cooled with HIWC followed by RC (refrigerated cooling) (6.81\%) and HIW (ice water) $(7.03 \%)$, respectively.
\end{abstract}

Keywords: Calcium chloride, DFFB, fruit rot, hydrocooling

\section{Introduction}

Apple (Malusxdomestica Borkh.) is a member of Rosaceae family and considered as one of the most economically important fruit trees of temperate zones (Martinelli et al., 2008). Agro-climatic conditions in hilly regions of Himachal Pradesh offer immense natural potential for increasing area and production under temperate fruits, especially apple. Though the area and production under apple cultivation in Himachal Pradesh has increased during the last few decades, but the productivity per unit area has not increased proportionally and is quite low as compared to the advanced apple growing countries of the world. The reasons for low apple productivity could be many, but one of them is the post harvest losses caused by different fungi.

There are a number of factors responsible for post harvest decays of fruits. The most important of these is maturity of fruits at harvest. Careless harvesting characterized by immature and over mature fruit is one of the serious causes of post harvest losses. Fruits harvested over mature tend to be soft and easily damaged during post harvest operations. Such fruits are more susceptible to diseases and physiological disorders as well as quality deterioration during and after storage.

Pre-cooling by removing field heat from freshly harvested fruits reduces microbial activity and respiration rates. Furthermore, the respiratory activity and senescence of fruit as well as ethylene production are temperature dependent. Due to the pre-cooling treatments, metabolic activity and consequently respiration rate and ethylene production of the fruits get reduced considerably. This also decreases the ripening rate, diminishes water loss and decay and thus helps preserving quality and prolongs shelf life of the fruits (Ferreira et al., 1994 and Reina et al., 1995). The process of heat removal from fresh produce can be achieved by several different methods, such as natural air cooling, forced air cooling, hydrocooling, ice cooling and vacuum cooling, each one differing in heat removal efficiency and processing cost.

\section{Materials and Methods}

\subsection{Fungal pathogens}

Isolates of Alternaria alternata, Monilinia fructigena, Trichothecium roseum, Aspergillus niger and Penicillium expansum were obtained from apple fruit samples (cv. Starking Delicious) expressing rot symptoms. Apple fruit samples were collected during survey made during 2015 and 2016 from different markets/stores/godowns of Shimla and Solan districts of Himachal Pradesh. The pathogens were isolated using standard phytopathological techniques. The diseased fruits were surface sterilized with absolute alcohol under aseptic conditions. Small bits of 1 to $2 \mathrm{~mm}$ size were taken from junction of diseased and healthy part of fruit with the help of sterilized sharp blade and scalpel. These bits were 
surface sterilized with sodium hypochlorite (1.0\%) for 10 to 20 seconds and washed thrice with sterilized distilled water under aseptic conditions. The bits were then placed on the sterilized filter paper to remove the excess moisture and subsequently transferred to sterilized Petri plates containing potato dextrose agar (PDA) medium. The inoculated Petri plates were incubated at $25 \pm 1{ }^{\circ} \mathrm{C}$ in BOD incubator and examined daily for mycelial growth. The fungal growth developed in Petri plates was purified by hyphal tip technique and was further cultured on slants containing PDA. These slants of culture were preserved at $5{ }^{\circ} \mathrm{C}$ in the refrigerator for further studies. Stock cultures were maintained by regularly sub-culturing after 20 to 25 days.

The causal organisms were identified by studying their morphology and comparisons with standard authentic descriptions from literature (Marie-Jose et al., 2004; Al-Hindi, 2011; Jurick, 2014; Hamid et al., 2014; Vico et al., 2014).

\subsection{Fruit inoculation}

Fruits were inoculated following Well method of Granger and Horne (1924). Wells were made on the fruit surface with the help of cork borer (internal diameter $5 \mathrm{~mm}$ ). The inoculum of $A$. alternata, $T$. roseum, $M$. fructigena, $A$. niger and $P$. expansum was placed at the bottom of wells and plugged back. These were further sealed with sterile paraffin wax.

\subsection{Effect of harvest maturity on post harvest rots of apple}

The fruits of apple cultivar Starking Delicious were harvested at three different stages of maturity at ten days interval during July-Aug representing early (106 DFFB), mid (116 DFFB) and late (126 DFFB) harvesting stage. Healthy trees of uniform size and good vigour were selected for harvesting fruit samples. Fruits showing the symptoms of surface damage or abnormalities were discarded while fruits of uniform size were selected and brought to the laboratory for the experiment. The selected fruits were washed under tap water; air dried for 15-20 min and then inoculated with the test pathogens by well method of Granger and Horne (1924). Each treatment was replicated thrice with five fruits per replicate for a particular test pathogen. After $12 \mathrm{hrs}$ of inoculation, the inoculated fruits were observed for fruit rot which was calculated by the formula given by Srivastava and Tondon (1968):

Fruit rot $(\%)=\frac{(\mathrm{W}-\mathrm{w})}{\mathrm{W}} \times 100$

Where,

$W=$ weight of the fruits before inoculation

$\mathrm{W}=$ weight of the fruits after removal of the rotten tissue

\subsection{Effect of pre-cooling on post harvest rots of apple}

Healthy fruits of apple cultivar Starking Delicious were harvested early morning during July-Aug. After harvesting, each fruit immediately sorted for size, colour and absence of defects; brought to laboratory and randomly held in fifteen lots ( 5 treatments $\times 3$ replicates). In order to see the effect of pre-cooling on post harvest rotting of apple, five separate treatments were chosen and used for post harvest cooling of apple fruits. The cooling methods used in the experiment are mentioned in Table 1.

Table 1: Details of pre-cooling methods studied against post harvest rots of apple

\begin{tabular}{|c|c|c|c|}
\hline $\begin{array}{l}\text { Treatment } \\
\text { codes }\end{array}$ & Cooling method & $\begin{array}{c}\text { Medium } \\
\text { temperature }\end{array}$ & $\begin{array}{l}\text { Cooling } \\
\text { time }\end{array}$ \\
\hline$A C$ & $\begin{array}{l}\text { Air-cooling (keep- } \\
\text { ing fruits in orchard } \\
\text { overnight) }\end{array}$ & $10^{\circ} \mathrm{C}$ & $12 \mathrm{~h}$ \\
\hline HTW & $\begin{array}{l}\text { Hydrocooling with } \\
\text { tap water }\end{array}$ & $14^{\circ} \mathrm{C}$ & $45 \min$ \\
\hline HIW & $\begin{array}{l}\text { Hydrocooling with } \\
\text { ice water }\end{array}$ & Close to $0^{\circ} \mathrm{C}$ & $30 \mathrm{~min}$ \\
\hline HIWC & $\begin{array}{l}\text { Hydrocooling with } \\
\text { ice water }+\mathrm{CaCl} 2 \\
(2 \% w / w)\end{array}$ & Close to $0{ }^{\circ} \mathrm{C}$ & $30 \mathrm{~min}$ \\
\hline $\mathrm{RC}$ & $\begin{array}{l}\text { Refrigerated cool- } \\
\text { ing }\end{array}$ & $4{ }^{\circ} \mathrm{C}$ & $30 \mathrm{~min}$ \\
\hline
\end{tabular}

After pre-cooling treatments, fruits were inoculated with the test pathogens separately by well method of Granger and Horne (1924). Each treatment was replicated thrice with five fruits per replicate for a particular test pathogen. Untreated (without pre cooling) inoculated fruits were kept as control for comparison. All treated and untreated fruits were placed at room temperature and observed for fruit rotting. After one week, the inoculated fruits were observed for fruit rot which was calculated after 6 days of inoculation by the formula given by Srivastava and Tandon (1968) as described earlier.

\section{Results and Discussion}

\subsection{Effect of harvest maturity on post harvest rots of apple}

The time and intensity of rot incidence depended on cultivar, harvest date and climatic conditions during the vegetation. More rot injuries were detected on apples picked later. A significantly smaller number of rotten apples were recorded in apples picked at optimum maturity. Starking Delicious apple cultivar was selected to study the effect of maturity at harvesting on post harvest rotting of apple. The fruits were harvested at three different stages representing early (106 DAFB), mid (116 DAFB) and late (126 DAFB) harvesting, artificially inoculated with the test fungi and data on $\%$ fruit rot was taken after 12 hours of inoculation (Table 2 ).

Apples picked later were more sensitive to rot with a mean rot of $76.21 \%$. At this stage, maximum fruit rot was observed in fruits inoculated with $P$. expansum $(87.22 \%)$ followed by $A$. niger (79.39\%). Early harvesting significantly resulted in minimum rotting of fruits (12.81\%). At this stage, maximum fruit rot was observed in fruits inoculated with $P$. expansum (23.70\%) followed by $A$. niger (15.56\%) whereas, 
Table 2: Effect of harvest maturity on post harvest rotting of apple after 12 hours of inoculation

\begin{tabular}{|c|c|c|c|c|c|c|c|}
\hline \multirow[t]{2}{*}{ Harvesting Stages } & \multirow[t]{2}{*}{ DFFB to maturity } & \multicolumn{5}{|c|}{ Fruit rot (\%) } & \multirow[t]{2}{*}{ Mean } \\
\hline & & A. alternata & T. roseum & M. fructigena & A. niger & P. expansum & \\
\hline Early (16 th Aug) & 106 & 8.19 & 11.56 & 5.05 & 15.56 & 23.70 & 12.81 \\
\hline Mid (26 th Aug) & 116 & 41.96 & 27.64 & 18.37 & 67.41 & 59.22 & 42.92 \\
\hline Late ( $5^{\text {th }}$ Sept) & 126 & 75.04 & 71.08 & 68.31 & 79.39 & 87.22 & 76.21 \\
\hline Mean & & 41.73 & 36.76 & 30.58 & 54.12 & 56.71 & \\
\hline
\end{tabular}

$\mathrm{CD}(p=0.05)$ Harvesting stages: 0.372; Test pathogen: 0.480; Harvesting stages $\times$ test pathogen: 0.831

M. fructigena and A. alternata recorded 5.05 and $8.19 \%$ fruit rot, respectively. Fruits harvested at 116 DAFB (mid harvesting stage) reported mean rot of $42.92 \%$. At this stage, maximum fruit rot was observed in fruits inoculated with $A$. niger (67.41\%) followed by $P$. expansum $(59.22 \%)$ and minimum with $M$. fructigena (18.37\%).

Development of rots during ripening and storage of apples depends on a range of pre harvest factors. The most important of these is maturity of fruits at harvest (Kvikliene, 2001; Ferguson et al., 1999). At the same time the cuticle is the first barrier that pathogens have to challenge (Ihabi et al., 1998). Later picked apples often are over mature and all physiological processes are underway what complicate storage, even under optimal conditions (Ingle et al., 2000; Braun et al., 1995). Apples harvested too late are vulnerable to mechanical injures, sensitive to low temperature breakdown, watercore and more rot (Hribar et al., 1996). Award et al. (1993) found that for Jonagold apples stored at $3 \%$ oxygen $+1 \%$ carbon dioxide the level of scald was $39 \%$ where the harvest was delayed compared with apples from a normal harvest date, where the level was $13 \%$. At optimal harvest time picked apples have the organoleptic qualities (Casals et al., 2006), which enable them to survive more than six months of storage. Identification of optimal harvest time raises a possibility of growing fruits less predisposed to rots and post harvest disorders (Kvikliene, 2004).

Careless harvesting characterized by immature and over mature fruit is one of the serious causes of post harvest losses (Ingle et al., 2000). Fruits harvested over mature tend to be soft and easily damaged during post harvest operations. Such fruits are more susceptible to diseases and physiological disorders as well as quality deterioration during and after storage (Lafer, 2006). Highest softening of apple fruits was observed when picked at climacteric peak and lowest one week before (Kvikliene et al., 2008).

\subsection{Effect of pre-cooling on post harvest rots of apple}

The results of effect of pre-cooling on post harvest rotting of apple cultivar Starking Delicious have been summarized in Table 3. Pre-cooling treatment with HIWC (ice water and calcium chloride) for $30 \mathrm{~min}$ was found most effective among all other cooling medium. Minimum fruit rot $(4.69 \%)$ was recorded in the fruits pre-cooled with HIWC followed by RC (refrigerated cooling) (6.81\%) and HIW (ice water) (7.03\%), respectively.

Under HIWC, maximum fruit rotting was observed due to $P$. expansum ( $8.26 \%$ ) followed by $A$. niger (5.53\%), A. alternata (4.17\%), T. roseum $(2.77 \%)$ and $M$. fructigena $(2.70 \%)$. Next

Table 3: Effect of pre-cooling on post harvest rotting of apple cv. Starking Delicious

\begin{tabular}{|c|c|c|c|c|c|c|c|c|}
\hline \multirow[t]{2}{*}{ Cooling Medium } & \multirow{2}{*}{$\begin{array}{l}\text { Cooling } \\
\text { time }\end{array}$} & \multicolumn{5}{|c|}{ Fruit Rot (\%) } & \multirow[t]{2}{*}{ Mean } & \multirow{2}{*}{$\begin{array}{c}\text { Control } \\
(\%)\end{array}$} \\
\hline & & A. alternata & T. roseum & M. fructigena & A. niger & P. expansum & & \\
\hline Air cooling & $12 \mathrm{~h}$ & 10.19 & 8.50 & 7.61 & 14.38 & 19.57 & 12.05 & 54.43 \\
\hline $\begin{array}{l}\text { Hydro cooling with tap } \\
\text { water }\end{array}$ & $45 \mathrm{~min}$ & 14.27 & 11.23 & 11.52 & 16.13 & 23.09 & 15.25 & 42.32 \\
\hline $\begin{array}{l}\text { Hydro cooling with ice } \\
\text { water }\end{array}$ & $30 \mathrm{~min}$ & 5.91 & 3.52 & 4.45 & 9.03 & 12.24 & 7.03 & 73.41 \\
\hline $\begin{array}{l}\text { Hydro cooling with ice } \\
\text { water }+\mathrm{CaCl}_{2}(2 \%)\end{array}$ & $30 \mathrm{~min}$ & 4.17 & 2.77 & 2.73 & 5.53 & 8.26 & 4.69 & 82.26 \\
\hline Refrigerated cooling & $30 \mathrm{~min}$ & 5.36 & 3.39 & 4.24 & 8.81 & 12.25 & 6.81 & 74.24 \\
\hline $\begin{array}{l}\text { Control (without pre- } \\
\text { cooling) }\end{array}$ & - & 24.72 & 22.78 & 25.13 & 27.65 & 31.94 & 26.44 & - \\
\hline Mean & - & 10.77 & 8.70 & 9.28 & 13.59 & 17.89 & - & - \\
\hline
\end{tabular}

$C D(p=0.05)$ Pre-cooling= 0.496; Test pathogen $=0.453$; Pre-cooling $\times$ Test pathogen $=1.109$ 
best cooling medium were AC (air cooling by keeping the fruits in orchard overnight) and HTW (tap water) with mean fruit rot of 12.05 and $15.25 \%$ as compared to control (26.44\%). Among different test fungi, $P$. expansum was recorded to give maximum fruit rotting followed by $A$. niger, $A$. alternata with mean rot of $17.89,13.59,10.77$ and $9.28 \%$, respectively. However, minimum fruit rot was observed in fruits inoculated with $T$. roseum (8.70\%).

Field heat is usually high and undesirable at harvesting stage of many fruits and vegetables and should be removed as quickly as possible before any post harvest handling activity (Bachmann and Earles, 2000). Excessive field heat give rise to an undesirable increase in metabolic activity minimizes the effect of microbial activity, metabolic activity, respiration rate and ethylene production (Shahi et al., 2012).

Calcium in the form of pectic substances is found primarily in the middle lamella and in the primary cell walls of plant tissues. It acts as cementing or cell binding material. Calcium has an important role in stability of cell wall structure, especially in fruits that are stored for relatively long time such as pears (Pooviah, 1988). Gradual infiltration of calcium to cell wall results in increasing level of $\mathrm{Ca}^{2+}$ ions in the cell wall and thus stabilizes it and protects the fruit against fungal and microbial contamination (Pooviah et al., 1991). Furthermore, post harvest treatment of Passe Crassane pear cultivar with $2 \%(\mathrm{w} / \mathrm{v})$ of $\mathrm{CaCl}_{2}$ solution followed by cold storage $\left(2^{\circ} \mathrm{C} \&\right.$ $90 \% \mathrm{RH}$ ) and ripening after storage for one week at $20^{\circ} \mathrm{C}$ not only prevented cellular wall and membrane degradation, but also decreased ethylene production and delayed its ripening process (Lara and Vendrell, 1998).

It was also found that firmness of Red Delicious apple is directly related to the calcium concentration in post harvest hydrocooling treatment (Conway and Sams, 1984). Chlorine solution in the form of sodium, potassium or calcium hypochlorite has been used to eliminate microorganisms for many years. To control Rhizopus, the responsible microorganism for whisker's rot in peaches, the best option is to use chlorine as the cheapest and most effective chemical compounds (Hopfinger, 1989).

\section{Conclusion}

Apples picked late (126 DAFB) were more sensitive to rots with a mean rot of $76.21 \%$. Early harvesting resulted in minimum rotting of fruits (12.81\%). Fruits harvested at 116 DAFB (mid harvesting stage) reported mean rot of $42.92 \%$. Pre-cooling treatment with HIWC (ice water and calcium chloride) for 30 min was found most effective among all other cooling medium. Minimum rotting (4.69\%) was recorded in the fruits pre-cooled with HIWC followed by RC (refrigerated cooling) (6.81\%) and HIW (ice water) (7.03\%). Thus, standardization of optimal harvest stage and pre-cooling method raises a possibility of harvested fruits less predisposed to rots and post harvest diseases.

\section{References}

Al-Hindi, R.R., Al-Nazada, A.R., Mohamed, S.A., 2011. Isolation and identification of some fruit spoilage fungi: Screening of plant cell wall degrading enzymes. African Journal of Microbiology Research 5, 443-448.

Awad, M.A.G., Jager, A., Roelofs, F.P., Scholtens, A., de Jager, A., 1993. Superficial scald in Jonagold as affected by harvest date and storage conditions. Acta Horticulturae 326, 245-249.

Bachmann, J., Earles, R., 2000. Post harvest Handling of Fruits and Vegetables, Appropriate Technology Transfer for Rural Areas. Fayetteville, NC, USA, 1-19.

Braun, H., Brosh, B., Ecker, P., Krumbock, K., 1995. Changes in quality of apples before, during and after CA-cold storage. Obstau Und Fruchteverwertung 45, 143-206.

Casals, M., Bonany, J., Carbo, J., Alegre, S., Iglesias, I., Molina, D., Casero, T., Recasens, I., 2006. Establishment of a criterion to determine the optimal harvest date of 'Gala' apples based on consumer preferences. Journal of Fruit and Ornamental Plant Research 14, 53-63.

Conway, W.S., Sams, C.E., 1984. Effects of calcium infiltration on ethylene production, respiration rates, soluble polyuronide content and quality of Golden Delicious apples. Journal of the American Society for Horticultural Science 109, 53-57.

Ferguson, I., Volz, R., Woolf, A., 1999. Preharvest factors affecting physiological disorders of fruit. Postharvest Biology and Technology 15, 255-262.

Ferreira, M.D., Brecht, J.K., Sargent, S.A., Aracena, J.J., 1994. Physiological responses of strawberry to film wrapping and pre-cooling methods. Proceedings of the Florida State Horticultural Society 107, 265-269.

Granger, K., Horne, A.S., 1924. A method of inoculating the apples. Annals of Botany 38, 212-215.

Hamid, M.I., Hussain, M., Ghazanfar, M.U., Raza, M., Liu, X.Z., 2014. Trichothecium roseum causes fruit rot of tomato, orange and apple in Pakistan. Plant Disease 98, 1271.

Hopfinger, J.A., 1989. The role of postharvest handling and peach skin discoloration. In: Coston, D.C.(Ed.), Technical Communications of International Society for Horticultural Science, 167-172.

Hribar, J., Plestenjak, A., Simcic, M., Vidrih, R., Patako, D., 1996. Influence of ecological conditions on optimum harvest date in Slovenia. In: de Jager, A., Johanson, D., Hohn, E. (Eds.), The Postharvest Treatment of Fruit and Vegetables. 49-51.

Ihabi, M., Rafin, C., Veighie, E., Sancholle, M., 1998. Storage diseases of apples: orchard or in storage. In: First transactional workshop on biological, integrated and rational control. Service Regional de la Protection des Vegetaux, Nord Pas-de Calais, 91-92.

Ingle, M., D'souza, M.C., Townsend, E.C., 2000. Fruit characteristics of York apples during development and after storage. HortScience 35, 95-98. 
Jurick, W.M., 2014. First report of Alternaria alternata causing post harvest decay on apple fruit during cold storage in Pennsylvania. Plant Disease 98, 690.

Kvikliene, N., Valiuskaite, A., Viskelis, P., 2008. Effect of harvest maturity on quality and storage ability of apple cv. 'Ligol'. Scientific works of the lithuanian institute of horticulture and lithuanian university of agriculture. Sodininkyste ir darzininkyste, 27.

Kvikliene, N., 2001. Effect of harvest date on apple fruit quality and storage ability. Folia Horticulturae 13, 97-102.

Lafer, G., 2006. Storability and fruit quality of 'Golden Delicious' as affected by harvest date, AVG and 1-MCP treatments. Journal of Fruit and Ornamental Plant Research, 14.

Lara, I., Vendrell, M., 1998. ACC oxidase activation by cold storage on "Passe-Crassane" pears: effect of calcium treatment. Journal of the Science of Food and Agriculture 76, 421-426.

Marie-Jose, Cote, Marie-Claude, Tardif, Allison, J.M., 2004. Identification of Monilinia fructigena, $M$. fructicola, $M$. laxa and Monilia polystroma on inoculated and naturally infected fruit using multiplex PCR. Plant Disease 88, 1219-1225.

Martinelli, F.M., Busconi, F., Camangi, C., Fogher, A., Stefani, Sebastiani, L., 2008. Ancient Pomoideae (Malus domestica Borkh. and Pyrus communis L.) cultivars in "Appenino Toscano" (Tuscany, Italy): molecular (SSR) and morphological characterization. Caryologia 61, 320-331.

Pooviah, B.W., Glenn, G.M., Reddy, A.S.N., 1991. Calcium and fruit softening physiology and biochemistry. Horticulture Review 10, 152-178.

Pooviah, B.W., 1988. Molecular and cellular aspects of calcium action in plant. HortScience 23, 267-271.

Reina, L.D., Fleming, H.P., Humphries, E.G., 1995. Microbial control of cucumber hydrocooling water with Chlorine Dioxide. Journal of Food Protection 58, 541-546.

Shahi, N.C., Lohani, U.C., Chand, K., Singh, A., 2012. Effect of precooling treatments on shelf life of tomato in ambient condition. International Journal of Food, Agriculture and Veterinary Sciences 2, 50-56.

Srivastava, M.P., Tandon, R.N., 1968. Influence of temperature on Botryodiplodia rot of citrus and sapodilla. Indian Phytopathology 21, 195-197.

Vico, I., Duduk, N., Vasic, M., Nikolic, M., 2014. Identification of Penicillium expansum causing postharvest blue mould decay of apple fruit. Pesticides and Phytomedicine 29, 257-266. 